\title{
Conservation tillage production systems compared in San Joaquin Valley cotton
}

\author{
by Jeffrey P. Mitchell, Daniel S. Munk, \\ Bob Prys, Karen K. Klonsky, Jon F. Wroble \\ and Richard L. De Moura
}

\begin{abstract}
Tillage operations, including preplant soil preparation, in-season weed control and postharvest stalk management, can account for $\mathbf{2 5} \%$ or more of overall cotton production costs. These operations reduce soil organic matter and contribute to air pollution.
\end{abstract} Conservation tillage practices similar to those used successfully elsewhere in the Cotton Belt may be a viable means for increasing profitability and improving soil in San Joaquin Valley cotton fields. In a comparison of reduced-tillage production methods, conservation tillage planting and stalk-management systems had yields comparable to those of standard tillage practices in two back-to-back cotton crops in Riverdale, Calif. These reduced-till systems decreased the number of tractor operations by $41 \%$ to $53 \%$, fuel use by $48 \%$ to $62 \%$, and overall production costs by $14 \%$ to $18 \%$.

Since the California Aqueduct opened as part of the Central Valley Improvement Project in 1963, cotton has been an important crop throughout much of the San Joaquin Valley. Cotton (Gossypium hirsutum) is routinely produced in rotation with other annual row crops including processing tomatoes, onions, garlic and melons, and field crops such as wheat and barley, particularly in the San Joaquin Valley's west side. Between 1992 and 2002, more than 750,000 acres of cotton on average were harvested annually from Merced County to the north through Kern County to the south. During this same period, however, production costs for cotton in some areas and years eclipsed the value of lint and seed, even with the federal support payments

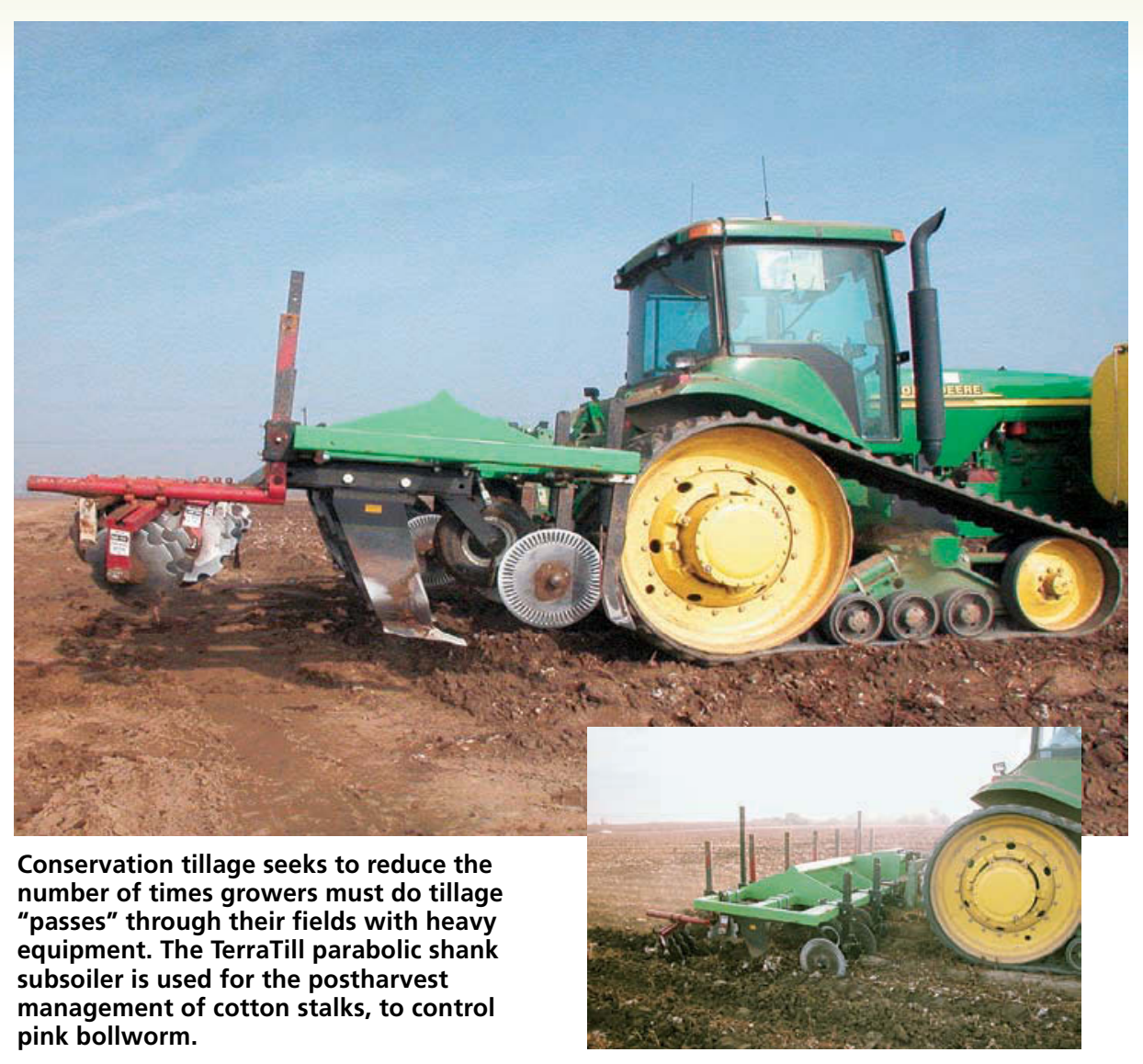

provided to producers. Improving profitability has become a clear mandate for sustained cotton production in the San Joaquin Valley.

An important management variable that producers can directly control is tillage. Preplant soil preparation, inseason weed control and postharvest stalk management are tillage-related operations in cotton production that can account for $25 \%$ or more of overall cotton-production costs (Carter 1996). These tillage operations represent not only high energy, equipment and labor costs, but they also reduce soil organic matter (Reicosky and Lindstrom 1995), and contribute air pollutants such as oxides of nitrogen and fine particulate dust (Baker et al. 2002). The adoption of conservation tillage (CT), or reducedtillage practices similar to those used successfully elsewhere in the Cotton Belt, may be a viable means for increasing profitability and improving the soil in San Joaquin Valley cotton fields.
"Conservation tillage" typically refers to a cropping system that leaves at least one-third of the soil covered with crop residue after planting. "Reduced tillage" systems have $15 \%$ to $30 \%$ residue on the soil surface after planting, while "no-till" systems have high crop residue content throughout the cropping season accompanied by little or no soil tillage throughout the year. On a nationwide basis, about 3.27 million acres $(29 \%)$ of cotton acreage used conservation tillage or reduced-tillage practices in 2002 (Towery 2002). From 1992 to 2002, no-till cotton acreage increased $740 \%$ in the United States, led by Georgia, North Carolina, Mississippi, Tennessee and Alabama (Towery 2002).

The need to control pink bollworm through tillage and crop residue management, the lack of inexpensive alternatives for preplant weed control and unfamiliarity with conservation tillage production systems are obstacles that have prevented the greater adoption of 


\begin{tabular}{|c|c|c|c|c|c|c|}
\hline \multicolumn{7}{|c|}{ Systems evaluated ${ }^{*} \dagger$} \\
\hline 1: Standard & 2: NT/chop & 3: NT & 4: RT/chop & 5: RT & 6: ST/chop & 7: ST \\
\hline Chop cover crop & Chop cover crop & $\begin{array}{l}\text { No-till plant } \\
\text { cotton with }\end{array}$ & Chop cover crop & $\begin{array}{l}\text { Ridge-till plant } \\
\text { cotton with }\end{array}$ & Chop cover crop & Strip-till seed bed \\
\hline Disk & $\begin{array}{l}\text { No-till plant } \\
\text { cotton with }\end{array}$ & JD 1730 planter & $\begin{array}{l}\text { Ridge-till plant } \\
\text { cotton with }\end{array}$ & $\begin{array}{l}\text { Buffalo } 8000 \\
\text { planter }\end{array}$ & Strip-till seed bed & $\begin{array}{l}\text { Plant cotton with } \\
\text { JD } 1730 \text { planter }\end{array}$ \\
\hline Disk & JD 1730 planter & $\begin{array}{l}\text { Apply glyphosate } \\
\text { over the top }\end{array}$ & $\begin{array}{l}\text { Buffalo } 8000 \\
\text { planter }\end{array}$ & Apply glyphosate & $\begin{array}{l}\text { Plant cotton with } \\
\text { JD } 1730 \text { planter }\end{array}$ & Apply glyphosate \\
\hline $\begin{array}{l}\text { Chisel } \\
\text { Disk }\end{array}$ & $\begin{array}{l}\text { Apply glyphosate } \\
\text { over the top }\end{array}$ & Cultivate & $\begin{array}{l}\text { Apply glyphosate } \\
\text { over the top }\end{array}$ & $\begin{array}{l}\text { over the top } \\
\text { Cultivate }\end{array}$ & $\begin{array}{l}\text { Apply glyphosate } \\
\text { over the top }\end{array}$ & $\begin{array}{l}\text { over the top } \\
\text { Cultivate }\end{array}$ \\
\hline List beds & $\begin{array}{l}\text { Cultivate } \\
\text { Harvest cotton }\end{array}$ & $\begin{array}{l}\text { Harvest cotton } \\
\text { Shred stalks }\end{array}$ & Cultivate & Harvest cotton & Cultivate & Harvest cotton \\
\hline $\begin{array}{l}\text { Plant cotton with } \\
\text { JD } 1730 \text { planter }\end{array}$ & Shred stalks & Root-pull stalks & Harvest cotton & Shred stalks & Harvest cotton & Shred stalks \\
\hline $\begin{array}{l}\text { Ring roll } \\
\text { Apply glyphosate } \\
\text { over the top } \\
\text { Cultivate }\end{array}$ & $\begin{array}{l}\text { Root-pull stalks } \\
\text { and/or TerraTill } \\
\text { subsoiler with } \\
\text { rotary harrows } \\
\text { to relist beds }\end{array}$ & $\begin{array}{l}\text { and/or TerraTill } \\
\text { subsoiler with } \\
\text { rotary harrows } \\
\text { to relist beds }\end{array}$ & $\begin{array}{l}\text { Shred stalks } \\
\text { Root-pull stalks } \\
\text { and/or TerraTill } \\
\text { subsoiler with } \\
\text { rotary harrows } \\
\text { to relist beds }\end{array}$ & $\begin{array}{l}\text { Root-pull stalks } \\
\text { and/or TerraTill } \\
\text { subsoiler with } \\
\text { rotary harrows } \\
\text { to relist beds }\end{array}$ & $\begin{array}{l}\text { Shred stalks } \\
\text { Root-pull stalks } \\
\text { and/or TerraTill } \\
\text { subsoiler with } \\
\text { rotary harrows } \\
\text { to relist beds }\end{array}$ & $\begin{array}{l}\text { Root-pull stalks } \\
\text { and/or TerraTill } \\
\text { subsoiler with } \\
\text { rotary harrows } \\
\text { to relist beds }\end{array}$ \\
\hline Harvest cotton & & & & & & \\
\hline Shred stalks & & & & & & \\
\hline Disk & & & & & & \\
\hline Disk & & & & & & \\
\hline Subsoil/relist beds & & & & & & \\
\hline
\end{tabular}

reduced tillage in San Joaquin Valley cotton (Carter 1996). While these are still formidable issues, recent innovations have made the prospect of developing reduced-tillage options for California cotton achievable. These include the introduction of reduced-pass rebedding equipment that facilitates pink bollworm plowdown compliance, the advent of various herbicide-resistant cotton varieties, and the availability of high surfaceresidue cultivators and planters.

\section{Farm tillage study}

To evaluate and refine possible conservation tillage systems for cotton, we initiated a study with Borba Farms in Riverdale, Calif., in fall 2000. Borba Farms is a 13,000 -acre diversified farm, located in south-central Fresno County, which produces a variety of crops including cotton, processing tomatoes, wheat, alfalfa, sugar beets, garlic and onions. Three replications of seven cotton planting and postharvest stalk- management systems were set out in 30-inch beds across a 12-acre field (table 1). A standard crop-management approach (system 1) employing typical, currently used methods of planting and cotton stalk management was established as a reference or control plot.

Prior to each of the two cotton crops in the study, a winter cover crop of barley (Hordeum vulgare) was grown across the entire experimental field to add organic matter to the soil and improve tilth. The soil in this field is a Grangeville fine sandy loam, which is a coarser-textured soil than much of the cotton production land farther west in Fresno, Merced and Kings counties. Borba Farms routinely uses small-grain cover crops as a means to improve overall soil quality and reduce crop stand losses caused by blowing sands or inadequate bed moisture in their coarser-texture fields. These cover crops were seeded on Nov. 1, 2000, and Nov. 15, 2001. After about 3 months they were sprayed with the herbicide glyphosate and then disked, prior to reestablishing planting beds in the standard tillage system in late March of the following springs.

Three planting systems were evaluated alongside a conventional or standard tillage system: no-till, ridge-till and strip-till. In the no-till system, the only tillage is the soil disturbance in a narrow slot created by coulters or seed openers at planting. Ridge-till is a reduceddisturbance planting system in which crops are planted and grown on ridges (the equivalent of "peaked" beds) formed during the previous growing season and maintained with shallow in-season cultivation equipment. In the ridge-till system, planters sweep away or sheer off residues and soil in the seed line, but do not disturb much of the soil surface between rows. In strip-till, coulters cut residues ahead of subsoiling shanks, which loosen the soil from a few to as many as 14 inches ahead of a planter. 

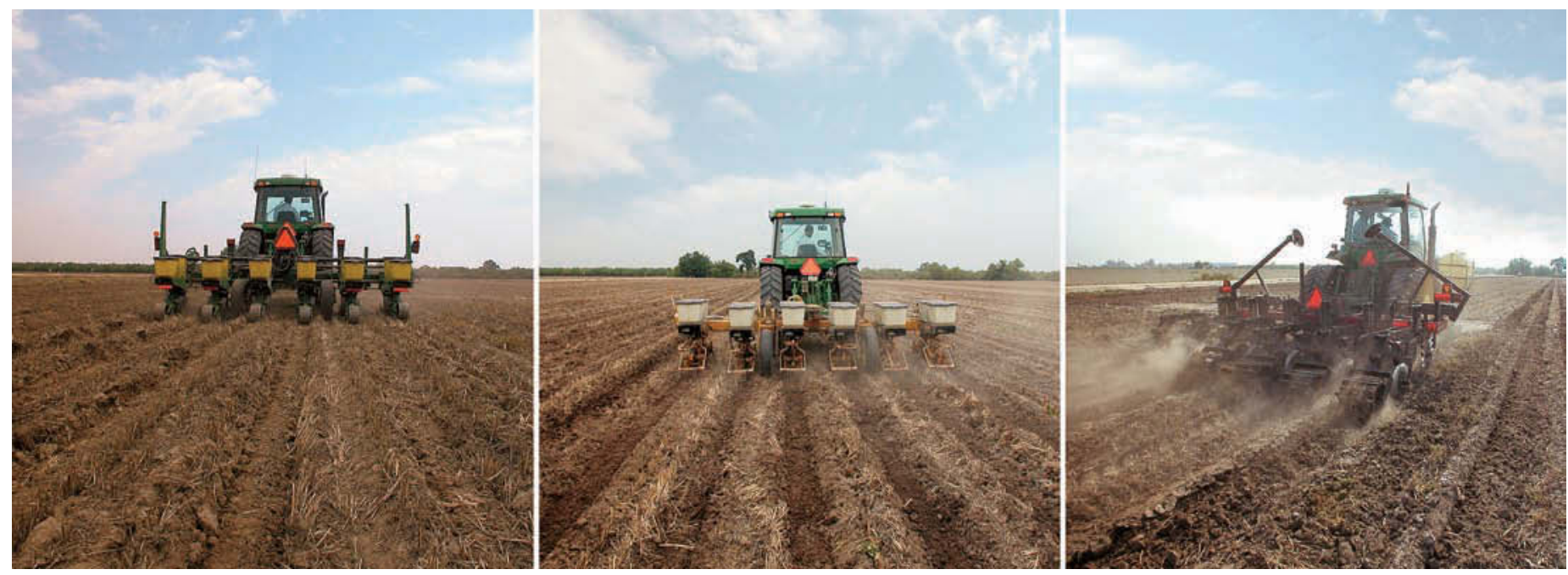

Left to right, no-till, ridge-till and strip-till planting into barley cover crops at Borba Farms, in Riverdale, Calif. These alternative tillage systems were compared to conventional tillage in cotton.

In each of these conservation tillage systems, only a small percentage of the soil surface is disturbed, unlike the "broadcast" tillage, or land preparation operations that are typically used in conventional tillage systems. Prior to planting, the cover crops in all three tillage systems were either sprayed with the herbicide glyphosate and chopped with a flail mower a week later (systems 2, 4 and 6) or only sprayed with glyphosate (systems 3, 5 and 7). A six-row, 30-inch John Deere 1730 (Moline, Ill.) planter was used in systems 1, 2, 3, 6 and 7, and a Buffalo 8000 Ridge-Till Planter (Fleischer, Neb.) was used in systems 4 and 5 . Each planter was calibrated to plant 58,000 seeds per acre with an expectation for standard final plant populations of at least 40,000 plants per acre. Riata, a conventional California glyphosate-tolerant (Roundup Ready) cotton variety, was used in both years of the study in all planting systems.

A global positioning system (GPS) tractor guidance system was used for the subsequent cotton planting in 2002 to maintain the integrity of the tillage plots. Following harvest of the 2001 and 2002 crops, cotton stalks in system 1 were shredded using a flail mower. These control plots were then disked twice and ripped to a depth of about 18 inches, then planting beds were reestablished using a TerraTill (Bigham Brothers, Lubbock, Texas) subsoiler shank fitted with bed-shaper shovels. Postharvest stalk management in each of the other systems consisted of shredding, root-pulling with a Sundance implement (Coolidge, Ariz.) and relisting beds (creating beds and furrows in a flat field) using the TerraTill parabolic shank subsoiler without shovels in 2001. In 2002, after the stalks were shredded, the beds were subsoiled and listed using disc-blade cultivator tools mounted at the back of the TerraTill implement. The conservation tillage systems differed from the standard tillage system in terms of presence of a cover crop, plus both preplant and postharvest tillage operations (table 1). The tillage systems were managed from the general principle of reducing tillage to the greatest extent possible while using generally available equipment and maintaining yields at desired levels.

Cotton stand establishment was monitored at about 1 month following planting each year by counting the number of emerged seedlings along 100 -foot lengths in each plot. Standard cotton-plant mapping procedures were used during each season to characterize crop growth and development. Yield was determined by machine harvesting and weighing lint and seed from the center four or eight rows in each six- or 12-row plot, respectively. Six-pound harvest samples from each plot were ginned at the UC Shafter Cotton Field Station. Gin turnout, or the lint percentage of the total sample by weight, was determined. We maintained records of all field operations, including implement width and tractor horsepower.

\section{Crop productivity}

Cotton plant populations generally adequate for optimal yields were achieved by each planting system in both years of our study, with the exception of ridge-till (systems 4 and 5) in 2002, when we set the seeding depth too low. Our test of the ability of these conservation tillage planting systems to achieve adequate stands in herbicide-sprayed and chopped cover crop (systems 2, 4 and 6) or herbicide-sprayed cover crop (systems 3,5 and 7) was only conducted in 2001 due to the fact that the cover crop was chopped in all systems in 2002.

However, a reduction in plant stands, as evidenced by the higher incidence of 3-foot skips (space between plants), was seen in both the no-till (system 2) and ridge-till (system 4) planting systems in the sprayed-only cover crop relative to the sprayed and chopped cover crop in 2002 (table 2). The evaluation of planted seed in the ridge-till plots indicated that average seed placement was about 4 to 5 inches deep. Seed germination and soil moisture were adequate to achieve an acceptable plant population, but the seedlings had difficulty emerging from these depths. Because stand establishment was generally adequate except in the 2002 ridge-till system, this singleyear evaluation of cover-crop management approaches requires additional testing to determine the relative benefits of herbicide spraying alone, or herbicide spraying in conjunction with chopping 
TABLE 2. Average number of plants per acre for cotton tillage-system evaluation at Borba Farms, Riverdale, Calif., 2001 and 2002, and percentage of field with plant skips greater than $3 \mathrm{ft}$. based on $100 \mathrm{ft}$. of sampled row, 2002

\begin{tabular}{|c|c|c|c|}
\hline Cover crop / tillage system* & 2001 & 2002 & $\begin{array}{c}2002 \\
(\geq 3 \mathrm{ft} . \text { plant skips })\end{array}$ \\
\hline & \multicolumn{2}{|c|}{ Avg. no. plants/acre } & $\%$ field \\
\hline 1: Standard & 34,200 & 44,500 & 1.3 \\
\hline 2: NT/chop & 41,200 & 45,500 & 8.6 \\
\hline 3: NT & 34,500 & 42,600 & 10.6 \\
\hline 4: RT/chop & 39,500 & 21,200 & 32.0 \\
\hline 5: RT & 34,500 & 19,900 & 23.5 \\
\hline 6: ST/chop & 39,000 & 38,200 & 13.8 \\
\hline 7: ST & 46,800 & 39,800 & 11.3 \\
\hline
\end{tabular}

* NT/chop = no-till with cover crop chopped; NT = no-till; RT/chop = ridge-till with cover crop chopped; $\mathrm{RT}=$ ridge-till; ST/chop = strip-till with cover crop chopped; $\mathrm{ST}=$ strip-till.

TABLE 3. In-season plant height and fruiting nodes, June 11; height, fruiting nodes and nodes above white flower (NAWF) on July 17, 2002, Borba Farms, Riverside, Calif.

\begin{tabular}{|c|c|c|c|c|c|c|c|}
\hline & \multicolumn{7}{|c|}{ Cover crop/tillage system* } \\
\hline & 1: Standard & 2: NT/chop & 3: NT & 4: RT/chop & 5: RT & 6: ST/Chop & 7: ST \\
\hline \multicolumn{8}{|l|}{ June 11} \\
\hline Height (inches) & $7.4 a+$ & $5.8 \mathrm{bc}$ & $5.8 \mathrm{bc}$ & $5.4 c$ & $5.4 \mathrm{c}$ & $5.8 \mathrm{bc}$ & $6.5 b$ \\
\hline Fruiting nodes & $2.6 a$ & $1.6 \mathrm{~b}$ & $1.5 b c$ & $1.1 \mathrm{bc}$ & $0.6 \mathrm{c}$ & $1.1 \mathrm{bc}$ & $1.8 \mathrm{~b}$ \\
\hline \multicolumn{8}{|l|}{ July 17} \\
\hline Height (inches) & $35.3 \mathrm{~cd}$ & $34.3 e$ & $38.8 \mathrm{ab}$ & $35.6 \mathrm{~cd}$ & $35.8 \mathrm{~cd}$ & $39.7 a$ & $37.0 \mathrm{bc}$ \\
\hline Fruiting nodes & $11.2 c$ & $11.2 c$ & $11.8 b c$ & $12.8 \mathrm{a}$ & $11.6 c$ & $12.5 a b$ & $11.6 c$ \\
\hline NAWF & $4.2 \mathrm{e}$ & $8.0 \mathrm{~b}$ & $5.0 \mathrm{~d}$ & $9.0 \mathrm{a}$ & $6.7 c$ & $7.8 \mathrm{~b}$ & $6.3 c$ \\
\hline \multicolumn{8}{|c|}{$\begin{array}{l}\text { * NT/chop = no-till with cover crop chopped; NT = no-till; RT/chop = ridge-till with cover crop chopped; } \\
\text { RT = ridge-till; ST/chop = strip-till with cover crop chopped; ST = strip-till. }\end{array}$} \\
\hline
\end{tabular}

prior to conservation tillage seeding. These follow-up studies are under way.

Irrigation "checks" or borders divided the study field, and water was applied using open valves. Each check was about 200 feet long. No difficulties were observed in terms of advancing water down these checks in any particular tillage treatment.

In-season plant monitoring data assisted us in identifying contrasting cotton growth and development patterns between tillage treatments that affected crop performance. Differences in surface residue cover, for instance, can modify the crop microclimate by changing the reflected surface radiation and soil sensible heat balance. Cover-crop residues remaining on the soil surface are highly reflective and often result in lower surface soil temperatures, thereby reducing plant growth (Van Doren and Allmaras 1978), and can result in reduced early-season plant growth. About 2,183 pounds of cover-crop residue (dry weight) in 2000 and 1,346 pounds in 2001 were present on the soil surface at the time of planting. Plant mapping measurements conducted in June found shorter plants with fewer fruiting branches for the tillage treatments having high surface-residue content (table 3). The conventional tillage treatment had produced one to two additional fruiting branches by June 11, 2002. Generally, however, differences in plant height and fruiting-node number were minimal by mid-July.

Mid- and late-season plant monitoring also included the evaluation of nodes above white flower (NAWF), an indicator of crop maturity or earliness. The conventional tillage treatment had consistently lower NAWF values, indicating that conventional tillage encouraged crop earliness and alternative tillage delayed crop maturity. In locations where crop earliness is favorable, this may be a drawback to the use of alternative tillage practices.
Yield data from this study reveals important management strategies that may be used to further develop and optimize conservation tillage cotton production systems in the San Joaquin Valley. In both years, strip-till prior to planting - a more aggressive seedbed preparation practice - had the most consistent yields, averaging 1,307 pounds of lint per acre in 2001 and 1,251 pounds per acre in 2002. In the light or sandy soil at this experimental site, strip tillage provided seedbed conditions that were fully adequate for crop establishment, growth and development.

In 2001, the two strip-till systems (systems 6 and 7) yielded more cotton lint than the standard tillage control (system 1). System 3, no-till planting into standing herbicide-killed covercrop residue, had the lowest yields of the conservation tillage systems in 2001. In 2002, the decreased plant populations in the two ridge-till systems corresponded to significantly lower lint yields relative to the standard-till system and the other conservation tillage systems. In that year, an extra pass with a "ring roller" implement was made in system 1 . We believe this operation improved seed contact with moist soil at planting, which resulted in improved seedling emergence and early-season vigor.

\section{Postharvest stalk management}

Effective control of pink bollworm (Pectinophora gossypiella), a pest that damages cotton bolls and has cost the U.S. cotton industry billions of dollars over the years, has been a long-standing priority of San Joaquin Valley cotton producers. A major strategy for pink bollworm control, which has been highly successful for more than 30 years in the San Joaquin Valley, is an IPM approach largely based on a pest-monitoring program and the controlled use of a biological control method. Components of the system include a minimum "host-free" period in which no cotton plants are available as hosts to the pest. This minimum period is from mid- to late December (last date for cutting plant stems from the roots and incorporating plant residue) through 


\section{Developing an attitude for change may become increasingly popular if more successful examples of conservation tillage production systems can be demonstrated.}

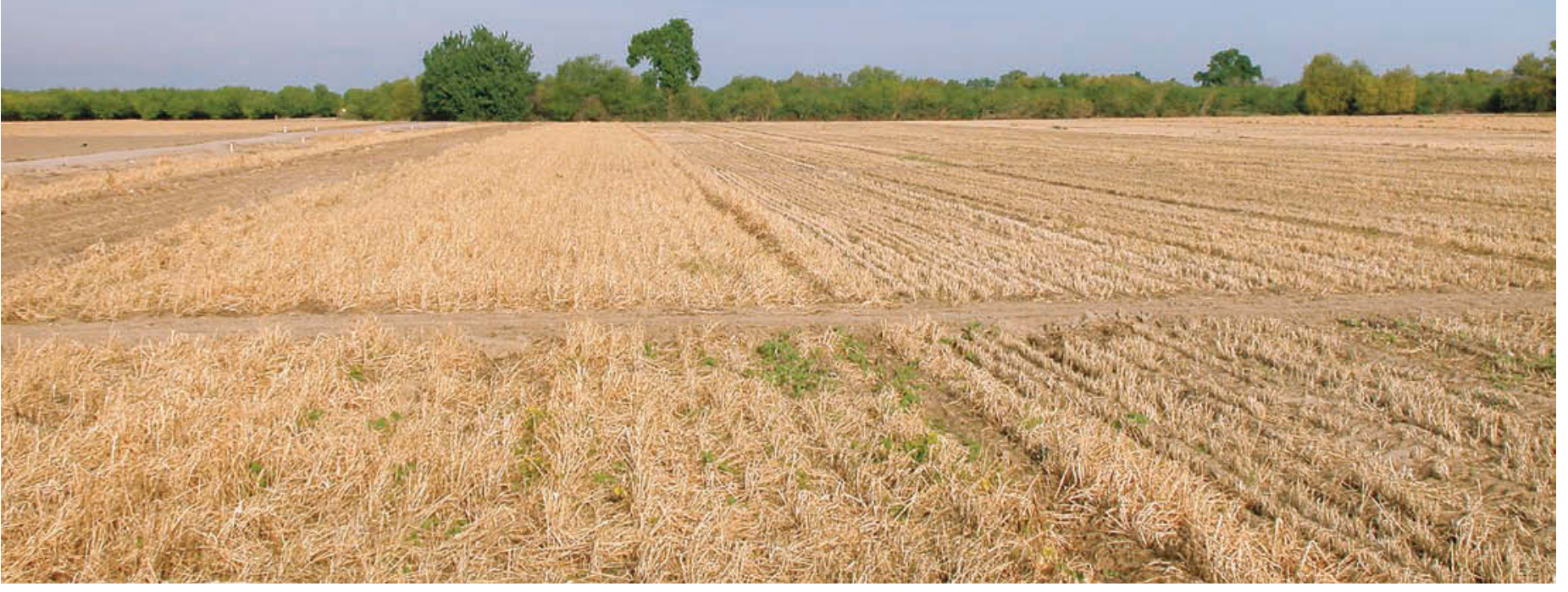

At Borba Farms, cover crops were managed several different ways prior to cotton planting. Left center, herbicides were sprayed on the cover crop; right, the cover crop was sprayed and chopped; far left, the cover crop was disked in.

March 10 (earliest allowed planting date in the San Joaquin Valley). Other parts of the pink bollworm control program include monitoring pink bollworm adults in pheromone-baited traps placed throughout California cotton fields, followed by the targeted release of sterile moths to disrupt normal mating.

In this study, we evaluated two systems for reduced-pass cotton stalk management. At the end of the 2001 crop, we used a sequence of operations that involved shredding, root-pulling and subsoiling using a TerraTill "bent leg" shank. This series of operations was effective

TABLE 4. Cotton yields for tillage systems, Borba Farms, Riverdale, Calif., 2001 and 2002

\begin{tabular}{|c|c|c|}
\hline $\begin{array}{l}\text { Cover crop/ } \\
\text { tillage system* }\end{array}$ & 2001 & 2002 \\
\hline & \multicolumn{2}{|c|}{ lb. lint/acre } \\
\hline 1: Standard & $993 c \dagger$ & $1,311 a$ \\
\hline 2: NT/chop & $1,183 a b c$ & $1,258 a$ \\
\hline 3: NT & $1,081 b c$ & $1,215 a$ \\
\hline 4: RT/chop & $1,292 \mathrm{ab}$ & $709 b$ \\
\hline 5: RT & $1,229 a b c$ & $809 \mathrm{~b}$ \\
\hline 6: ST/chop & $1,352 a$ & $1,278 a$ \\
\hline 7: ST & $1,262 \mathrm{ab}$ & $1,223 a$ \\
\hline \multicolumn{3}{|c|}{$\begin{array}{l}\text { * NT/chop = no-till with cover crop chopped; NT = no- } \\
\text { till; RT/chop = ridge-till with cover crop chopped; RT = } \\
\text { ridge-till; ST/chop = strip-till with cover crop chopped; } \\
\text { ST = strip-till. }\end{array}$} \\
\hline \multicolumn{3}{|c|}{$\begin{array}{l}\text { † Means followed by different letters differ significantly } \\
(P<0.05) \text {. }\end{array}$} \\
\hline
\end{tabular}

in killing cotton plants throughout each of the conservation tillage systems and was given a provisional clearance by the Kings County agricultural commissioner. Following the 2002 crop, the same series of operations was repeated, except that the TerraTill was fitted with sets of double rotary disc harrows, known as "Go Devils," mounted behind to throw up beds in a single-pass operation. This sequence of postharvest operations was also highly successful in killing cotton plants and was deemed in compliance with pink bollworm stalk-management requirements by the local agricultural commissioner.

\section{Practical lessons}

This study revealed the short-term feasibility of using conservation tillage planting and stalk-management systems to produce cotton in California's San Joaquin Valley, with adequate yield, quality and pest management outcomes for this site's production standards. The study was conducted in a commercial production field and represents a reasonable scale of operation for current cotton production systems in the San Joaquin Valley. Lint yields in all of the treatments equaled average Fresno County yields in 2001, but were about 150 pounds per acre below average in 2002. Yields of each of the alternative tillage systems equaled or exceeded the yield of the standard tillage system in the first year, while yields in the 2002 standard tillage system were numerically, though not statistically, higher than the alternative tillage systems (table 4). The ridge-till systems had significantly lower yields in 2002, largely

\begin{tabular}{|c|c|c|c|c|c|c|c|}
\hline & \multicolumn{7}{|c|}{ Cover crop/tillage system* } \\
\hline & 1: Standard & 2: NT/chop & 3: NT & 4: RT/chop & 5: RT & 6: ST/chop & 7: ST \\
\hline Times over field & 17 & 9 & 8 & 9 & 8 & 10 & 9 \\
\hline Gallons of fuel & 19.5 & 8.5 & 7.5 & 8.5 & 7.5 & 10.2 & 9.2 \\
\hline Total operating costs & $\$ 237$ & $\$ 199$ & $\$ 195$ & $\$ 199$ & $\$ 195$ & $\$ 204$ & $\$ 200$ \\
\hline
\end{tabular}




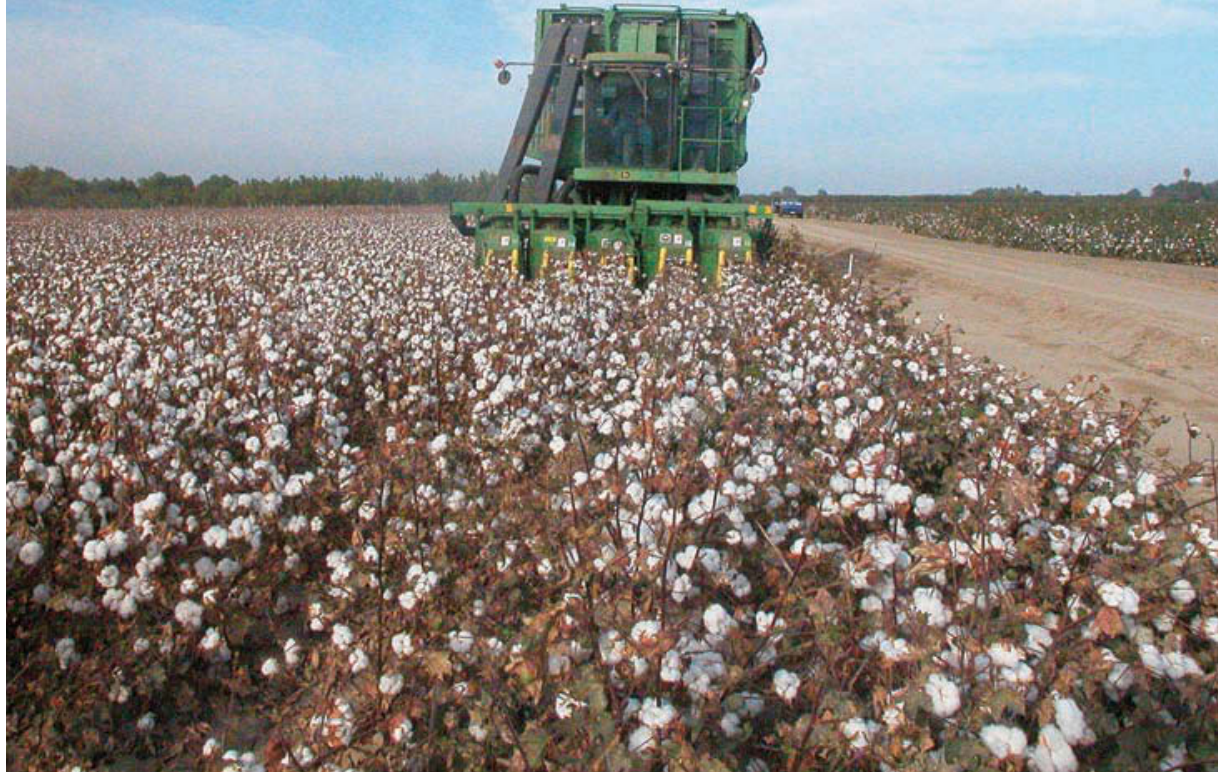

due to the problems encountered with reduced plant stands. While these alternative tillage systems all delayed crop maturity (table 3) and reduced the earliness of fruit-set, there were adequate heat units during the 2002 season to compensate for any differences with no significant influence on yield.

Yield is an important determinant of farm profitability, but reducing inputs and operational costs are other ways to affect a farm's bottom line. The conservation tillage systems evaluated in this study reduced the number of tractor operations used to produce a cotton crop by $41 \%$ to $53 \%$, depending on the system (table 5). This corresponded to an estimated reduction in fuel use of $48 \%$ to $62 \%$, and a reduction in overall production costs of $14 \%$ to $18 \%$. By extrapolation and based on companion studies we have recently completed, we would expect that a corresponding decrease in direct particulate-matter emissions would be achieved by the conservation tillage alternatives relative to the conventional tillage system.

Converting to reduced-till production alternatives, however, requires a number of significant operational changes, and each of these requires an upfront investment in additional equipment, time and management in order to be successful.
The operating agronomist at Borba Farms committed considerable time and thought to each of the management issues he faced during the course of this work. His behind-the-scenes "trial and error" innovation is not borne out in any of the cost estimates we have presented here. This component was indispensable for the success of this study.

For major changes to be implemented in overall agricultural production systems such as those we evaluated, "attitude" is often cited as a prerequisite for success (Bradley 2002). Developing an attitude for change may become increasingly popular if more successful examples of conservation tillage production systems can be demonstrated (Mitchell et al. 2002). Large-scale research and demonstration efforts at this farm site have provided promising results in terms of yield responses and the ability to reduce tillage passes and costs. Collectively, the researchers and growers demonstrated that specific variations of reduced-tillage systems can be successfully used for a 2-year cottoncotton rotation, with yields similar to conventional tillage and significant reductions in production and labor costs. Further tests are needed to help answer questions about how soil texture, crop rotation, and residue type and amount influence yield responses and alternative tillage choices.
In this study, lint yields were comparable to the regional average for all treatments during the first year, but yields in the alternative tillage systems were somewhat below average in the second year. However, fuel use in the alternative systems was reduced $48 \%$ to $62 \%$, and production costs were down $14 \%$ to $18 \%$. Left, cotton harvest.

J.P. Mitchell is Cooperative Extension Specialist, Department of Plant Sciences, UC Davis; D.S. Munk is Farm Advisor, UC Cooperative Extension (UCCE), Fresno County; B. Prys is Agromanager, Borba Farms, Riverdale, Calif.; K.K. Klonsky is Cooperative Extension Specialist, Department of Agricultural and Natural Resource Economics, UC Davis; J.F. Wroble is Field Technician, UCCE Fresno County; and R.L. De Moura is Production Cost Analyst, Department of Agricultural and Natural Resource Economics, UC Davis. We are grateful for the generous and unwavering support of Borba Farms, which enabled this study.

\section{References}

Baker J, Southard R, Mitchell J. 2002. Agricultural dust production in standard and conservation tillage systems in the San Joaquin Valley. In: Proc Conservation Tillage 2002: Research and Farmer Innovation Conf. Sept. 17, 2002, Davis, CA; Sept. 19, 2002, Five Points, CA. p 60-71.

Baker JB, Southard RJ, Mitchell JP. 2005. Agricultural dust production in standard and conservation tillage systems in the San Joaquin Valley. J Environ Qual 34:1259-60.

Bradley JF. 2002. Twenty-five year review of conservation tillage in the southern U.S.: Perspective from industry. In: Van Santen E (ed.). Making Conservation Tillage Conventional: Building a Future on 25 Years of Research. Proc 25th Annual Southern Conservation Tillage Conference for Sustainable Agriculture, Auburn, AL; June 24-6, 2002. Spec Rep No 1, Alabama Agric Expt Stn/Auburn Univ. p 20-4.

Carter LM. 1996. Tillage. In: Cotton Production Manual. UC DANR Pub 3352. p 175-86.

[CDFA] California Department of Food and Agriculture. 2006. Pink Bollworm Management Program. www.cdfa.ca.gov/phpps/ipc/pinkbollworm/ pbw_hp.htm.

Mitchell JP, Miyao EM, Jackson JJ, et al. 2002 Developing information on conservation tillage production systems in California. In: Proc Conservation Tillage 2002: Research and Farmer Innovation Conf. Sept. 17, 2002, Davis, CA; Sept. 19, 2002, Five Points, CA. p 10-2.

Reicosky DC, Lindstrom MJ. 1995. Impact of fall tillage on short-term carbon dioxide flux. In: Lal R, Kimble J, Levine E, Stewart BA (eds.). Soils and Global Change. CRC Lewis Publ. p 177-87.

Towery D. 2002. National Crop Residue Management Survey. Conservation Tillage Data. Conservation Technology Information Center, W. Lafayette, IN. www.ctic.purdue.edu/CTIC/CRM.html.

Van Doren Jr DM, Allmaras RR. 1978. Effect of residue management practices on soil physical environment, microclimate and plant growth. In: Oschwald WR (ed.). Crop Residue Management Systems. Spec Publ 31. American Society of Agronomy, Madison, WI. p 49. 